\title{
Article
}

\section{Taiwaneseness revisited: Lasting themes and new trends in contemporary popular culture}

\author{
Zemanek, Adina Simona
}

Available at http://clok.uclan.ac.uk/25271/

Zemanek, Adina Simona ORCID: 0000-0002-7960-8646 (2017) Taiwaneseness revisited: Lasting themes and new trends in contemporary popular culture. East Asian Journal of Popular Culture, 3 (2). pp. 139-152. ISSN 2051-7084

It is advisable to refer to the publisher's version if you intend to cite from the work. http://dx.doi.org/10.1386/eapc.3.2.139_2

For more information about UCLan's research in this area go to http://www.uclan.ac.uk/researchgroups/ and search for <name of research Group>.

For information about Research generally at UCLan please go to http://www.uclan.ac.uk/research/

All outputs in CLoK are protected by Intellectual Property Rights law, including Copyright law. Copyright, IPR and Moral Rights for the works on this site are retained by the individual authors and/or other copyright owners. Terms and conditions for use of this material are defined in the policies page.

\section{CLoK}

Central Lancashire online Knowledge www.clok.uclan.ac.uk

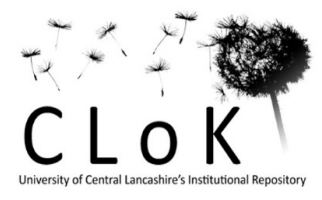




\title{
INTRODUCTION
}

\section{TAIWANESENESS REVISITED: LASTING THEMES AND NEW TRENDS IN Contemporary Popular Culture}

\author{
Adina Zemanek \\ Jagiellonian University in Krakow
}

The year 2017 marks two round anniversaries of significant events in Taiwan's history, related to violence and its official end: the February 28 Incident of 1947 and the lifting of martial law in 1987. The 1980s also ushered in a process of national re-definition that involved turning away from a China-centered paradigm imposed by the KMT authoritarian government towards a hitherto marginalized indigenous culture. Attempts to define it resulted in the emergence of a Taiwanese consciousness (Taiwan yishi) and an intensified quest for 'Taiwaneseness' (Taiwanxing) as 'specificity of the Taiwanese people' (Taiwan guozu texing) (Hsiau 2012: 11), which makes the topic of the present special issue of the East Asian Journal of Popular Culture. The search for a distinct Taiwanese identity was reflected in the scholarly, literary, artistic and political discourses, practices related to heritage preservation and other fields, with history, cultural memory, or national geography among the central kinds of social knowledge that underwent reformulation. It was also manifested in the rise of Taiwan as part of the curriculum in state education at all levels (Wang 2005, Chang 2006), and of Taiwan studies as a research field that gained both local and international recognition.

The fact that national identity is one of the few topics which have monopolized English-language academic research into Taiwan (Taylor 2010: 183) reflects the fluidity of 'Taiwan' as a sign and the ever-elusive character of Taiwanese national identity as a perceived imperative and target of continuous de-naturalizing attempts at discursive (re-)formulation (Harrison 2009). Taiwan is thus the subject of many stories that interact and compete with each other for hegemony or visibility. Some of these narratives inscribe the island within dominant epistemes (China or Western modernity); they are told by academics and taken over by polarized party politics that reproduces these structures of domination (Harrison 2015). However, such stories are incomplete; they co-exist with other politically constitutive narratives, equally partial and negotiated, which emerge from people's lived, everyday experiences of Taiwan's transformation and modernization. Harrison (2015) places particular emphasis on art as a practice that engages with memory in order to build meaningful, albeit marginal and subjective stories that contest dominant structures and formal knowledge makers. He singles out art for its capacity to engage with the violence underlying Taiwan's history, repressed but incessantly resurfacing as a haunting malaise.

It was also during the 1980s that the New Wave cinema began to tell stories of the so-called 'Taiwanese experience', a concept related to economic development and political change since the 1950s and 1960s (Song 1993). These works stood in stark contrast with other post-1945 genre movies that could be classified either as political propaganda or escapism (martial arts films or romantic melodramas), or which depicted idealized and static images of the countryside (the 'healthy realism' of the 1960s) (Hong 2011: 111). New Wave cinematic works linked the individual and the national, memory and history, through personal narratives of growing up set against the background of profound political, economic and social transformations and events significant for Taiwan as a whole. They were instances of collective memory, defined by Marita Sturken (1997: 45) as the dynamic, political practices by which individuals and groups produce memory outside, in response to or as resistance against officially sanctioned narratives constructed by the 'historical apparatus' (the academia and state institutions) (Popular Memory Group 1998: 76). They challenged official historiography through individual stories that exemplified collective traumas 
hitherto suppressed in the master narrative. Although it was these alternative stories that gained high international acclaim and recognition for Taiwan at a time of diplomatic defeats, they were criticized for representing experiences relevant for smaller groups, unable to interpellate an entire national community (Wu 1990). Kuan-Hsing Chen (2001: 55) writes of two divergent 'emotional structures of feeling' (qingxu jiegou) reflected in films from the early 1990s and resulting from different historical experiences (the Japanese colonization and the Cold War), which produced different identities and subjectivities and became the source of ethnic conflicts, causing the impossibility of constructing a shared 'imagined community' and of a 'great reconciliation' between native Taiwanese and Mainlanders. Moreover, the art house New Wave, extensively discussed in existing academic research (Lu 1998, Hong 2011, Berry and Lu 2005, Yu and Davis 2005, among many others), was a short-lived phenomenon referred to by its media critics as 'box office poison' (Hong 2011: 118).

The emergence of the New Wave was made possible by an official project aimed at rebuilding the cinema industry and raising standards for local productions. The process of Taiwanization mentioned above was parallel with democratization, which created a space for a plurality of voices to join in discursive definitions of Taiwaneseness. State endorsement for local arts and cultural industries began in the 1990s; with its advent to power, the DPP further distanced itself from KMTsupported high culture and time-honored folklore towards the cultural and creative industries, with special attention to their economic potential (Lu 2002: 43-47, Chang 2004: 6). This trend was continued during Ma Yingjiu's presidency (2008-2016) despite anxieties about a perceived 'deTaiwanization' and 're-Sinicization' also discernible in that period's cultural policy. Current president Tsai Ing-wen's culture-related program outlined before the 2016 elections emphatically returns to the DPP policy of placing Taiwan at the center (2015a), and expresses standing commitment to the development of the creative economy. Within this framework, a lasting preoccupation with specifying the meaning of the sign 'Taiwan' has led to proliferation of texts of popular culture that both undertake this mission and appeal to the public.

Moreover, the domination of intellectual and political elites whose role in formulating a Taiwanese consciousness and identity is discussed in Hsiau's studies informed by cultural nationalism (2012, 2008) is now challenged by a different kind of cultural elite - the so-called wunianji generation (people born during the fifth decade of the Republic of China, i.e. the 1960s). Members of this generation played a significant role in the formation of Taiwanese democracy through their involvement in social movements; their habitus was shaped by opportunities created by the 'economic miracle' already well under way when they came of age, and regular consumption of popular culture. The earlier ethnic polarization between native Taiwanese (benshengren) and Mainlanders (waishengren) became blurred for these people who were likely to display attachment to their home soil (Taiwan) and commitment to a local identity despite the influence of sinocentric KMT-controlled state education. Due to their current age, the wunianji generation enjoys an already established position in various fields: business, politics, the academia and cultural life; they are likely to look back over the past and involve in inter-generational exchange with their children, now in the late teens and twenties. In many respects, the wunianji resemble the American 1960s generation discussed by Ron Eyerman and Bryan Turner (1998), as well as Mike Featherstone (2007). The latter elaborates on the role of the 1960s generation as 'new cultural intermediaries', positioned between the media and academic and intellectual circles, acting as both producers or disseminators and consumers of cultural goods, also engaged in creating guidelines for a certain lifestyle inspired by artistic and intellectual trends. The wunianji have a distinct generational awareness and identity (articulated by Zhang Ruichang in China Times Editorial Office 2013: 7 and in the prefaces to Lin 2012 and Chuang 2013), express political views that go beyond the traditional green (DDP) / blue (KMT) divide (Li, Chen, Wu et.al. 2007), and are also markedly present among the authors and publishers of many texts of popular culture that tackle significant issues related to 
Taiwaneseness - one is them is Wei Desheng (b. 1969), the film director, screenwriter and producer discussed by Frederik H. Green in this issue.

Considering these manifold transformations, it is worthwile to track the newest stage of the discourse of Taiwaneseness as articulated in contemporary popular culture in order to asses the extent to which it continues already existing topics and approaches or makes new contributions. This is the task which the current issue of the East Asian Journal for Popular Culture undertakes through articles designed as analyses of popular texts or that combine text analysis with a discussion of practices related to production and reception, and often adopt a diachronic, comparative perspective. The following sections will briefly introduce each of these articles against a larger background that depicts various themes in the discourse of Taiwaneseness represented in contemporary popular culture.

\section{National Identification - China and Taiwan}

The process of Taiwanization greatly altered the China-centered identification promoted by the KMT during the martial law era, leading to a new official and popular consensus around an emerging local identity. The education system, one of the key fields involved in the state-led construction of national identity, joined in the attempts at formulating and disseminating knowledge about Taiwanese culture. The first discussions concerning educational reforms were taken up in the late 1980s and resulted in the approval (in 1997) of a Taiwan-focused high school history and social studies curriculum and a set of textbooks entitled Getting to Know Taiwan (Wang 2005, Lynch 2004: 515-516). The turn of the $21^{\text {st }}$ century ushered in further changes to the elementary and junior high curriculum, bringing Taiwan to the foreground in a broad range of subjects (Chang 2006: 199). This process was not a smooth one: it was accompanied by controversies, and the relative prominence granted to Chinese and Taiwanese culture has been subject to change either towards the former (with Ma Yingjiu's advocacy of Confucian ethics and the increased proportion of Classical Chinese and Chinese history courses in the high school program, which triggered protests against 'de-Taiwanization' - Hsiau 2012: 108, Hughes 2014: 123-124) or towards the latter (with the current proposals of further modifications to history courses - Lin 2017).

Studies of national identification in Taiwan from the recent decade show a general increase in the number of people identifying themselves exclusively as Taiwanese, paralleled by a decrease in Chinese identification (Chang 2006: 192, Ye 2010, Shen and Wu 2008, Taiwan Brain Trust 2016). This trend is reflected in Ye Chunjiao's research into identity shifts and the narrative construction of a Taiwanese identity in elite and popular accounts, based on materials published in leading daily newspapers (2010). A similar process of re-orientation towards the local is depicted by Lin Lijing, whose graphic memoir My Youth, My Formosa (2012, briefly analyzed by Heylen 2013) describes her childhood under martial law, when she internalizes the China-centered identity imposed by state education, and her university years in the 1990s, when she explores formerly repressed, traumatic national memories against the background of democratization and student political activism. Young Lin dissociates herself from her Hakka and Hoklo parents and Japanese-raised grandparents, displaces her center of national, geographic and historical belonging from her actual locality (Taiwan) and transfers it to China; as a young adult, she makes efforts to rebuild these previously dismantled bridges. Another graphic memoir by Sean Chuang also mentions Chinese nationalism imposed by martial-law education and media, as well as Bruce Lee's Hong Kong movies that sustained it on a popular level with Taiwanese viewers of all ages (2013: 15, 16, 73-76).

In the present issue, Chen-Yu Lin and Haekyung Um engage with the construction of Chineseness and Taiwaneseness in two popular songs: Jay Chou's Blue and White Porcelain (2006), which features traditional Chinese instruments and offers an idealized, nostalgic vision of ancient Chinese 
past, and Fire EX.'s Island Sunrise (2014), a song in Hokkien composed for the Sunflower Movement, regarded as its anthem and performed at the Legislative Yuan. In order to understand how the audience relate Chineseness and Taiwaneseness to their own identities by reflecting on their experience of these songs, the authors interviewed students between 18 and 25 years of age, members of a generation referred to as 'naturally independent'. Despite expressed affinity and familiarity with Chinese culture and language, interview participants emphasized a lack of connection with China as an actual geographical and political entity and uneasiness with the education they had received, which forced upon them knowledge of Chinese literature, history and geography. Although unambiguously positioning themselves as Taiwanese, the interviewed students showed that Taiwaneseness and Chineseness are not mutually exclusive, but two terms of a continuum as constantly negotiated, ever-changing narratives.

\section{Rewriting National History}

Many constructivist accounts of nationhood emphasize history's role in nation-formation processes. Benedict Anderson speaks of the nation as an entity growing from a past tradition constructed as a coherent narrative (1991: 9-36, 178-184, 197-20). Michael Billig argues that 'national histories are continuously being re-written, and the re-writing reflects current balances of hegemony' (1995: 7071). In Taiwan, too, the re-formulation of national identity has to a great extent consisted in rewriting history. History has been among the key disciplines revamped during educational reforms (including the most recent proposals), and was the bone of contention in disputes around the Getting to Know Taiwan textbook series (Wang 2005). Forcible ruptures in Taiwan's history and the need to restore continuity are still reiterated in the historical and political discourse. ${ }^{i}$

Marita Sturken and the Popular Memory Group speak of multiple sources contributing to the 'social production of memory' (Popular Memory Group 1998: 75-86). The two sites to which they belong (the 'historical apparatus' and 'cultural memory') are entangled rather than opposed to each other (Sturken 1997: 4-5). Memories are constructed and shared through mediated visual technologies: photographs, cinema, television and mass-produced commodities (Sturken 1997: 8, 2008: 75-76). The New Wave Cinema's small-scale stories of hitherto repressed traumas have already been mentioned. Lin Lijing's graphic memoir also takes oppositional stances towards past and present hegemonic discourses. Yang Cui's preface highlights the ethnic, generational and historical cleavages caused by the KMT authoritarian rule, the need to reshape historical consciousness and restore 'the island's memory map' by recovering lost 'shards of memory' (2012, vol. 1: 13-14). In the memoir itself, the narrator's quest for recovering her Taiwanese identity involves revealing acts of violence committed during the martial law period, passed over in silence by official history.

According to Pierre Nora (1996: 1-20), collective rituals enabling experiences of the past that would naturally induce a sense of community have been replaced by an obsession with archiving and remembrance as sources of identity, which has to be reflexively constructed by individuals in an inherently fragmented contemporary world. Reconstructions of history are micro-scale and invoke the immediacy of personal experience by their marked sensual dimension. Lash (1990: 80, 97-98) also points out the shift from signification to sensation, the primacy of the bodily and material characteristic of postmodernism. In Taiwan, there is a salient preoccupation with recording, reconstructing and commemorating the past in small-scale, individual narratives and in forms that appeal to the senses by emphasizing the materiality, concreteness and immediacy of memories and vestiges of the past. These traits may reflect the contemporary condition characterized by a rupture between history, memory and the nation as discussed by Nora (1996: 13), but may also be symptomatic of a profound desire to restore the unity between these three elements. 
The obsession with recording history is visible everywhere, in popular practices aimed at constructing lieux de mémoire in Nora's terms: various forms of commemorating the Japanese past (by reinterpretating historical figures such as the engineer Hatta Yoichi - Amae 2015); commercial spaces - old-style shops selling sweets, beverages and toys on the verge of disappearing as actual spaces but reconstructed through exhibitions and in popular books (Xiao 2010); illustrated history books (Zhou 2016); book series commemorating specific periods through key trends, events and artefacts displayed in colourful pictures (Yuanliu Visual Book Editorial Office 2002); comic books for a young audience narrating the past in a dramatized, graphic form and in ordinary historiographical discourse illustrated with historical documents and old photographs (such as the Creative Comic Collection edited from 2009 to 2015 by Academia Sinica - Chen 2009); collectible postcards with reproductions of old maps, periodicals, advertisements, merchandise packaging, consumer goods, photographs of popular singers, baseball players, political figures etc. from the Japanese colonial period to the 1980s (such as those published by Xiaocao Studio or Monkey Design). To paraphrase the title of Xiao's book quoted above, these visual and material reconstructions turn the black-and-white past into colourful, compelling and pleasurable memories with a tint of nostalgia. Corrado Neri (2016) speaks of a retro mania in contemporary Taiwan, embodied in many aspects of everyday life and visual culture, which he discusses at length with reference to recent films. He quotes studies that perceive the retro trend in a negative sense of stagnation or as an instance of bricolage that pays ironic or sentimental homage to the past at the level of style or form (2016: 7-23). However, he also approaches the retro wave in Taiwan as a means for evaluating the present through the lens of the past, or of assessing the latter's significance in a contemporary light (2016: 26-28).

In the 1980s, the revalorization of the Japanese colonial period by academics and its incorporation into Taiwan's history went against the grain of martial-law era official accounts that adopted a China-centered perspective and positioned Japan as the national enemy and ruthless exploiter. Nowadays, positive accounts of the Japanese rule have become mainstream. Scholarly studies dedicated to economic issues, public hygiene, education, the women's movement and other topics have revealed Taiwan's advancement during the colonial era. This standpoint is salient in numerous texts of popular culture that touch upon the period of Japanese rule and reflected in a general nostalgia for the colonial era among the Taiwanese. Cinematic representations of this period are a popular research topic. Tze-lan Sang (2012) and Kuei-fen Chiu (2007) appraise to what extent the nostalgia-tinted documentary Viva Tonal: The Dance Age (2003) displays complicity with Japanese colonialism or critical reflection on it. Frederik H. Green's article in this issue shows that nostalgia in Taiwanese films should not be read as a simple eulogy for the colonial era, but as a site for complex negotiations regarding Taiwan's global position, contemporary China-related politics, diversity and multiculturalism. Through content analysis of Wei Desheng's films and a discussion of the uses which Sunflower student protesters made of KANO in 2014, Green argues (in line with Sang 2012: 64) that Taiwan's postcolonial nostalgia is politically motivated. The idealization of Japan constitutes a form of identity formulation and resistance against KMT authoritarian rule and Taiwan's growing dependency on China's economy that might undermine the island's national sovereignty.

\section{Taiwanese Subjectivity and Cultural Hybridity}

The re-writing of national history since the 1980s has been guided by the concept of 'Taiwanese subjectivity' (Taiwan zhutixing). Discussions on this topic emphasized the island's peripheralization throughout history, the belated and (hitherto) partial formation of subjectivity itself, and two tasks related to both directions of a temporal axis: that of re-writing history from a Taiwanese standpoint and of autonomously determining the island's future (Lynch 2004: 516-517). The former aim often leads to an apparent paradox - Taiwanese subjectivity seems to be expressed 
through embracing a lack thereof, as indicated in the remarks on positive revaluations of the Japanese colonial era as part of Taiwan's history and their political implications in a cross-strait context.

Although saliently present in recent historiography, popular culture or heritage preservation (Lu 2002, Amae 2011), Japan's is not the only foreign rule featured in the discourse of multiculturalism and hybridity which makes the foundation of the Taiwan-centered national paradigm. Spanish, Dutch, Qing rules and the indelible marks they left on Taiwan's culture were highlighted in postmartial law academic historiography and the Getting to Know Taiwan textbook series issued in the 1990s (Wang 2005: 75); a popular counterpart of such accounts, the historical television documentary series Taiwan: A People's History (2007), is analyzed by Daw-Ming Lee (2012); manifold outside cultural influences and their unique combinations with local factors are emphasized in community building projects (Lu 2002); Taiwan's openness to the world and its readiness to incorporate global elements are discussed by authors of both popular publications (China Times Editorial Office 2013: 6-7) and academic works on nation building in Taiwan (Lynch 2004: 514-515); these topics are also given great prominence in texts that expound president Tsai Ing-wen's stances on culture-related issues (Tsai 2015).

An awareness of Taiwan's cultural hybridity is shaped by many contemporary tourist souvenirs featuring sites or objects related to various periods of outside political domination. It is also displayed in Sean Chuang's graphic memoir (2013), whose chapters depict foreign practices, objects and texts that have acquired local meanings and become part of local life - the abovementioned Bruce Lee movies that sustained a China-centered identity, baseball - a game introduced to Taiwan by the Japanese, which through Taiwanese international victories scored in the late 1960s and the 1970s asserted a global status for the island at a time of diplomatic setbacks, or Japanese toy robots coveted by Taiwanese children, depicted by Chuang as objects of family negotiations. The chronological table appended to the book juxtaposes Taiwan and world history by listing major events in popular culture instead of politics. It positions Taiwan as inhabiting a modern temporality and a global space, with no time lag in the island-bound transnational dissemination of popular culture, a sense of coevalness discussed by Keichi Iwabuchi (2002: 122). Cultural diversity is also mentioned in Shizong Xie's analysis of Wei Desheng's film Cape No. 7 (2008) (2015: 109-113).

Wei-Chih Wang's article featured in this issue, which testifies of the impossibility to draw clear boundaries between high and low culture characteristic of postmodernism (Lash 1990), focuses on two international theatrical productions - Orlando (2009), an adaptation of Virginia Woolf's novel with the same name directed by the American Robert Wilson, and La Dame aux Camélias (2011), Suzuki Tadashi's interpretation of Alexandre Dumas fils' original novel. In his analysis of the two plays and their reception in Taiwan, Wang adopts Patrice Pavis' hourglass model of intercultural theatre in its extended version proposed by Jacqueline Lo and Helen Gilbert, and shows that the two instances of transnational cooperation reflect a Taiwanese yearning for representing the local by employing universalist values and establishing global connections. Wang takes into account three different and sometimes conflicting perspectives belonging to the foreign directors, local practitioners and Taiwanese spectators, to give a multifaceted account of the complex forces involved in this not always successful dialogue between universal or Western values and local cultural frameworks.

\section{National Geography and First-hand Experience of Taiwan as Epistemological Method}

The Taiwan-centered paradigm that arose in the 1980s also involved re-mapping Taiwan by breaking its former links to continental China. Bi-yu Chang (2015: 68-69, 99) points out that maps are used to shape national imagination, assert political domination and territorial sovereignty. She 
tracks geographic imagination in Taiwan during the Japanese rule, under the martial law and within the indigenization movement. Before the late 1980s, the official KMT discourse promoted nostalgia for a home located in mainland China through the construction of collective memory linked to that territory, accompanied by 'a sense of placelessness and an attitude of spatial indifference' related to Taiwan (Chang, 2015: 175, 192). National maps published in Taiwan and data concerning the national territory provided by official statistical yearbooks pertained to mainland China, a kind of national imagination whose slow demise is discussed by Wang (2013). By contrast, the process of Taiwanization introduced an alternative, island-centered perspective, intensified after the DPP's advent to power in 2000 and manifested in initiatives that challenged conventional views upon Taiwan, such as two series of maps launched in 2003 by the Council for Cultural Affairs. The first series was designed from a Taiwanese standpoint that combined geography and history through highlighting early Han settlers' perspective on the island, or Taiwan's geological and linguistic kinship with Southeast Asia; the second one, depicting Taiwan as seen by foreign eyes, was a selection of old maps from historical archives (Chang 2006: 197-198). These official projects were paralleled by popular interest in collecting antique maps during the 1990s and early 2000s (Chang, 2015: 69-70, 92-93), reflected in currently available reproductions of such maps for the general public (such as those issued by SMC Publishing) and in a series of collectible postcards designed by Xiaocao Studio.

The state emphasis on culture construction and on developing the cultural and creative industries that began under the KMT in the late 1980s and 1990s and gained momentum after the DPP's rise to power has resulted in various branding initiatives carried out since the turn of the $21^{\text {st }}$ century (Chang 2006: 195-197). Some of these were designed as complex, large-scale nation branding projects: the Tourism Bureau's 'Taiwan - Touch Your Heart' campaign, revamped in 2011 with a new slogan: 'Taiwan - The Heart of Asia'. A central theme of the latter is the promotion of cycling trips around the island and within various tourist areas, recurrent in many videos commissioned by the Tourism Bureau and available on its website ${ }^{\text {ii }}$. Nation branding is adopted as framework of reference in a study of tourist souvenirs (Zemanek 2017) that construct a sense of national identity by de-naturalizing everyday objects and sights that are present everywhere across the island but usually go unnoticed. The same elements are employed as signifiers of history to construct a national heritage by challenging the viewer to discover the stories that lie behind them. Thus both national identity and national history are made readily available through first-hand, everyday, sensorial experiences.

Ssu-Fang Liu Jessie's article explores all the above mentioned themes - an interest in Taiwan's geography, around-the-island trips, cycling and personal, sensorial experience as an epistemological method. The author places her topic in a historical perspective and argues that during the Qing rule and the Japanese colonial era, geographical knowledge about Taiwan constructed the island as part of a larger political entity centered elsewhere. By contrast, the interest in around-the-island trips that arose in the 2000s is related to a first-hand, bodily involvement with Taiwan as object of knowledge, an epistemological model that replaces the visual domination characteristic of previous times. The diachronic view Liu adopts also concerns cinematic history: her analysis focuses on films depicting around-the-island journey produced in various periods, from Brother Wang and Brother Liu Tour Taiwan (1958) to Island Etude and The Most Distant Course, released in 2007.

\section{Ethnic Divisions and the Taike}

New Wave and slightly later films depicted traumas and experiences typical to either of the two ethnic groups in Taiwan - the native Taiwanese and the Mainlanders. Hou Hsiao-hsien's City of Sadness (1989) portrays a native Taiwanese family right after Japan's retrocession of Taiwan to the Republic of China and the sufferings caused to its members by the 228 Incident. The main character 
of Wu Nianzhen's A Borrowed Life (1994) is a native Taiwanese 'historical orphan' whose quixotic loyalty to Japan is an act of resistance (or excape) towards the KMT's recolonization of Taiwan and violent repressions against the 1947 massacre that stigmatized his fate (Davis 2005, Liao 1997).

Wang Tong's Banana Paradise (1989) discloses the trauma of the Mainlanders' forced displacement and the persecutions they underwent during the White Terror (Hong 2011: 139-158). Edward Yang's A Brighter Summer Day (1991), set in 1961, also tackles the White Terror and depicts two groups of Mainlanders still only precariously anchored in Taiwan. A Time to Live, A Time to Die by Hou Hsiao-hsien (1985) deals with the issue of postmemory, discussed in Hsiau's study of young Mainlander intellectuals in the 1960s, affected by their parents' 'exilic mentality' and China-related homesickness (2010).

Wang (2003: 81) speaks of shared history and life experiences, and of different development paths after Taiwan's separation from China, which gave rise to a feeling of social solidarity among all people living on the island, native Taiwanese and Mainlanders alike, who came to imagine themselves as citizens of a state located within the geographic area under actual control of the nationalist government. It is this spirit that underlay the concept of 'community of shared fate' (mingyun gongtongti), promoted by former president Lee Teng-hui during the 1990s and defined by Wang (2003: 81). The idea of the 'four great ethnic groups' (native Taiwanese, Mainlanders, Hakka and Aborigines) that constitute Taiwanese society emerged during the same period as another attempt at bridging ethnic boundaries, and became a dominant frame of reference for the entire national community.

However, despite a decreased relevance of ethnic boundaries for the wunianji generation and younger people due to mixed marriages and a growing identification with Taiwan as a home, these boundaries do not seem to have been fully erased, a fact illustrated by the taike. This stereotype, based on several kinds of rifts (ethnic, cultural, geographic and political) emerged during the 1950s, when it was used by Mainlanders as a derogatory label for the native Taiwanese. It continued to be employed through the 1980s to denote people of disorderly and vulgar behaviour, substandard as compared to an elite ideal of high culture and good taste associated with the Mainlanders. The taike also connoted the Hokkien-speaking southern Taiwan as opposed to the Mandarin- and Mainlanderdominated Taipei. This non-elite stereotype underwent positive revalorization in the $1990 \mathrm{~s}$, when it was endorsed by representatives of the DPP and advocates of Taiwan's independence, and promoted as an epitome of Taiwanese culture. The heyday of 'Taike culture' fell in 2005 and the following years, with heated media discussions and a proliferation of cultural products related to this topic - 'Taike Rock' music, popular books (Xian 2005), films, or theatrical and dance performances incorporating elements of 'temple fair' aesthetics, Taiwanese opera and puppetry.

The positive revaluation of the taike and its association with the superordinate category of Taiwaneseness have not yet bridged the divides underlying it. Cape No. 7, the film which greatly contributed to shaping current popular imagination about the taike, builds its humorous effect on these very divides: it is set in the southernmost town of Hengchun, its central characters display many sartorial, behavioural and linguistic traits of the taike, and the utopian final harmony that prevails over initial ethnic and national differences excludes the Mainlanders (Xie 2015: 110). Niu Chengze's Monga (2010) also reproduces the taike stereotype, although the film can also be read to advocate social solidarity for Taiwan under common threat posed by the 'China factor' through its ethnically ambiguous central character (Mosquito) and his fate. Texts such as Sean Chuang's memoir and the tourist souvenirs mentioned above, which promote a sense of national identity grounded in everyday places and objects, borrow the taike's non-elite connotations but move them from people to a vernacular, mundane culture typical of Taiwan as a whole.

Apart from research articles, the current issue also includes Sydney Hsin-I Yueh's personal response to a controversy triggered by popular group Nine One One's music video Foreigner (2015) and an 
American student's negative reaction to it in a clip containing accusations of racism uploaded on YouTube, which in turn sparked a heated debate among Taiwanese netizens. In Yueh's view, informed by her scholarly, critical perspective, the dispute went beyond racial issues and revealed deep-seated stereotypes, prejudices and forms of discrimination that still divide the Taiwanese society, related to gender, skin colour, national status, and the cultural hierarchies that favour an urban, middle-class lifestyle, Mandarin Chinese and the general category of 'good taste' over rurality, Hokkien and a general lack of sophistication still attributed to the taike and employed by Nine One One to build their public image.

\section{Gender, Historical Traumas and Transitional Justice}

The five major reforms proposed by current president Tsai Ing-wen in her electoral program included transitional justice - the courage to disclose and face historical truth concerning the use of violence by Taiwan's previous authoritarian rulers, and to gradually wipe up the damage it caused (2015b). While the sustainability of her approach is to be verified from a long-term perspective, the last article related to the topic of this special issue, Yi-Huei Mary Wang's review of Shawna Yang Ryan's Green Island (2016), shows the lasting relevance of marginal stories and art as a means for dealing with painful memories, emphasized by Mark Harrison in his speech quoted at the beginning of this introduction. Wang's text, a short analysis of the novel, points out that Ryan employs the first-person woman's narrative as a form (in Raymond Williams' terms) that allows her to present an alternative view of history that challenges the hegemonic masculine point of view hitherto dominant in the discourse of Taiwanese nationalism. While this point resounds with Sydney Yueh's observation that the positive connotations acquired by the taike stereotype in its recent associations with Taiwanese culture only regard men, the future will show to what extent Ryan's literary vision of Taiwan as 'woman' will be further developed in more popular texts.

\section{References}

Amae, Yoshihisa (2011), 'Pro-colonial or Postcolonial? Appropriation of Japanese Colonial Heritage in Present-day Taiwan', Journal of Current Chinese Affairs, 40: 1, pp. 19-62. (2015), 'A Japanese Engineer Who Became a Taiwanese Deity: Postcolonial

Representations of Hatta Yoichi', East Asian Journal of Popular Culture, 1, pp. 33-51. Anderson, Benedict (1991), Imagined Communities, London \& New York: Verso.

Berry, Chris and Lu, Feii (2005), Island on the Edge: Taiwan New Cinema and After, Hong Kong: Hong Kong University Press.

Billig, Michael (1995), Banal Nationalism, London, Thousand Oaks, New Delhi: SAGE.

Chang, Bi-yu (2004), 'From Taiwanisation to De-sinification. Culture Construction in Taiwan since the 1990s', China Perspectives, 56, pp. 2-17.

(2006), 'Constructing the Motherland: Culture and the State since the 1990s', in Dafydd Fell, Henning Klöter and Bi-Yu Chang (eds.), What Has Changed? Taiwan Before and After the Change in Ruling Parties, Wiesbaden: Harrassowitz Verlag, pp. 187-206.

(2015), Place, Identity and National Imagination in Postwar Taiwan, London and New York: Routledge.

Chen, Kuan-hsing (陳光興) (2001), 'Wei shenme da hejie bu/keneng? Duosang yu Xiangjiao Tiantang zhimin/lengzhan xiaoying xia shengji wenti de qingxu jiegou' ('Why is the Great Reconciliation Im / Possible? De-Cold War / De-Colonization, and Ethnically Relevant Emotional Structures of Feelings'), Taiwan: A Radical Quarterly in Social Studies, 43, pp. 41-110.

Chen, Yixuan (陳怡璇) (ed.) (2009), CCC chuangzaoji (Creative Comic Collection), vol. 1, Taipei: Gaiya wenhua. 
China Times Editorial Office (中國時報編輯部) (2013), Taiwan guanjianzi: shi'er ge shehui xin dongli (Taiwan Keywords: Twelve New Social Motive Forces), Taipei: Tianxia Yuanjian.

Chiu, Kuei-fen (2007), 'The Vision of Taiwan New Documentary', in Darrell William Davis and Robert Ru-shou Chen (eds.), Cinema Taiwan. Politics, Popularity and State of the Arts, London and New York: Routledge, pp. 17-32.

Chuang, Sean (小莊) (2013), 80 niandai shijian bu (Diary of the 80s in Taiwan), Taipei: Dala.

Davis, Darrell William (2005), 'Borrowing Postcolonial. Wu Nianzhen's Dou-san and the Memory Mine', in Sheldon Lu and Emilie Yeh Yueh-yu (eds.), Chinese-Language Cinema's Historiography, Poetics, Politics, Honolulu: University of Hawaii Press, pp. 237-266.

Eyerman, Ron and Turner, Bryan S. (1998), 'Outline of a Theory of Generations', European Journal of Social Theory, 1: 1, pp. 91-106.

Featherstone, Mike (2007), Consumer Culture and Postmodernism, Los Angeles, London, New Delhi and Singapore: SAGE.

Harrison, Mark (2009). 'How to Speak about Oneself. Theory and Identity in Taiwan', in Chris Berry, Nicola Liscutin, and Jonathan Mackintosh (eds.), Cultural Studies and Cultural Industries in Northeast Asia. What a Difference a Region Makes, Hong Kong: Hong Kong University Press, pp. 51-70.

(2015), 'Art, Violence and Memory: Retelling the Story of the Beautiful Island', keynote speech presented at the conference 'Taiwan: The View from the South', Canberra, 9 January, http://ciw.anu.edu.au/events/2015/taiwanconference/. Accessed 14 December 2016.

Heylen, Ann (2013), 'Reading History and Political Illustration in Taiwan Popular Culture', Oriental Archive, 81, pp. 1-25.

Hong, Guo-juin (2011), Taiwan Cinema. A Contested Nation on Screen, New York: Palgrave Macmillan.

Hsiau, A-chin (蕭阿勤) (2008), Huigui xianshi: Taiwan 1970 niandai de zhanhou shidai yu wenhua zhengzhi bianqian (Return to Reality: Political and Cultural Change in the 1970s Taiwan and the Postwar Generation), Taipei: Institute of Sociology, Academia Sinica.

- (2010), 'A “Generation in Itself”: Authoritarian Rule, Exilic Mentality, and the Postwar Generation of Intellectuals in 1960s Taiwan', The Sixties: A Journal of History, Politics and Culture, 3: 1, pp. 1-31.

(2012), Chonggou Taiwan: dangdai minzuzhuyi de wenhua zhengzhi (Reconstructing Taiwan: The Cultural Politics of Contemporary Nationalism), Taipei: Lianjing.

Hughes, Christopher R. (2014), 'Revisiting Identity Politics under Ma Ying-jeou', in Jean-Pierre Cabestan and Jacques deLisle (eds), Political Changes in Taiwan under Ma Ying-jeou.

Partisan Conflict, Policy Choices, External Constraints and Security Challenges, Abingdon and New York: Routledge, pp. 121-136.

Iwabuchi, Keichi (2002), Recentering Globalization. Popular Culture and Japanese Transnationalism, Durham and London: Duke University Press.

Lash, Scott (1990), Sociology of Postmodernism, London and New York: Routledge.

Lee, Daw-Ming (2012), 'Re/making Histories. On Historical Documentary Film and Taiwan: A People's History', in Sylvia Li-chun Lin and Tze-lan D. Sang (eds.), Documenting Taiwan on Film. Issues and Methods in New Documentaries, London and New York: Routledge, pp. 1137.

Li, Dingzan (李丁讚), Chen, Zhangwen (陳長文), Wu, Xianghui (吳祥輝) et. al. (2007), Di san shehui de xiangxiang. Chaoyue duikang, zouxiang gongtong weilai (Imagining the Third Society. Transcending Antagonisms, Towards a Common Future), Taipei: Tianxia Yuanjian.

Liao, Chaoyang (1997), 'Borrowed Modernity: History and the Subject in A Borrowed Life', boundary 2, 24: 3, pp. 225-245.

Lin, Lijing (林莉菁) (2012), Wo de qingchun, wo de FORMOSA (My Youth, My Formosa), vols. 12, Taipei: Wuxian. 
Lin, Xiaoyun (林曉雲) (2017), 'Shehui xin kegang: Zhongguo lishi fang Dongya mailuo taolun’ ('New Social Science Curriculum: China to Be Discussed within the Topic of East Asia'), Ziyou shibao, June 19.

Lu, Feii (盧非易) (1998), Taiwan dianying: zhengzhi, jingji, meixue, 1949-1994 (Taiwan Cinema: Politics, Economy, Aesthetics, 1949-1994), Taipei: Yuanliu.

Lu, Hsin-yi (2002), The Politics of Locality. Making a Nation of Communities in Taiwan, New York and London: Routledge.

Lynch, Daniel C. (2004), 'Taiwan's Self-Conscious Nation-Building Project', Asian Survey, 44: 4, pp. 513-533.

Neri, Corrado (2016), Rétro Taiwan. Le temps retrouvé dans le cinéma sinophone contemporain (Retro Taiwan. Time Regained in Contemporary Sinophone Cinema), Paris: L'Asiathèque.

Nora, Pierre (1996), 'General Introduction: Between Memory and History', in Pierre Nora (ed.), Conflicts and Divisions, vol. 1 of Realms of Memory. Rethinking the French Past (trans.

Arthur Goldhammer), New York: Columbia University Press.

Popular Memory Group (1998), 'Popular Memory. Theory, Politics, Method', in Robert Perks and Alistair Thomson (eds.), The Oral History Reader, London and New York: Routledge, pp. 7586.

Sang, Tze-lan D. (2012), 'Reclaiming Taiwan's Colonial Modernity. The Case of Viva Tonal: The Dance Age', in Sylvia Li-chun Lin and Tze-lan D. Sang (eds.), Documenting Taiwan on Film. Issues and Methods in New Documentaries, London and New York: Routledge, pp. 60-88.

Shen, Shiau-chi and Wu, Nai-teh (2008), 'Ethnic and Civic Nationalisms: Two Roads to the Formation of a Taiwanese Nation', in Peter Chow (ed.), The "One China” Dilemma, New York, Palgrave Macmillan, pp. 117-143.

Song, Guangyu (宋光宇) (ed.). (1993). Taiwan jingyan (yi) - lishi jingji pian (The Taiwan Experience 1: History and Economy). Taipei: Dongda.

Sturken, Marita (1997), Tangled Memories: The Vietnam War, the AIDS Epidemic, and the Politics of Remembering, Berkeley: University of California Press.

- (2008), 'Memory, Consumerism and Media: Reflections on the Emergence of the Field', Media Studies 1: 1, pp. 75-76.

Taiwan Brain Trust (2016), '2016 Taiwan Brain Trust Trend Survey Results Press Conference', 8 November, http://en.braintrust.tw/article detail/2130. Accessed 29 June, 2017.

Taylor, Jeremy E. (2010), 'Qujianghua: Disposing of and Re-appraising the Remnants of Chiang Kai-shek's Reign on Taiwan', Journal of Contemporary History, 45: 1, pp. 181-196.

Tsai, Ing-wen (蔡英文) (2015a), 'Hou zhi wenhua li, dazao Taiwan wenyi fuxing xin shidai' ('Firmly Establishing the Strength of Culture, Forging a New Era of Taiwanese Renaissance'), http://iing.tw/posts/200. Accessed 28 March 2017.

- (2015b), 'Vote 2016: Tsai Ing-wen's Five Major Reforms', http://thinking-taiwan.com/vote-2016-tsai-ing-wens-five-major-reforms/. Accessed 4 July 2017.

Wang, Fu-chang (王甫昌) (2003), Dangdai Taiwan shehui de zuqun xiangxiang (Ethnic imagination in contemporary Taiwan), Taipei: Qunxue.

(2005), 'Why Bother about School Textbooks? An Analysis of the Origin of the Disputes over Renshi Taiwan Textbooks in 1997', in John Makeham and A-chin Hsiau (eds.), Cultural, Ethnic, and Political Nationalism in Contemporary Taiwan - Bentuhua', New York and Houndmills: Palgrave Macmillan, pp. 55-99.

- (2013), 'A Prolonged Exile: National Imagination of the KMT Regime in Postwar Taiwan', Oriens Extremus, 52, pp. 137-172.

Wu, Qiyan (吳其諺) (1990), ‘Taiwan jingyan de yingxiang suzao' ('Visual Depictions of the

Taiwanese Experience'). Dianying xinshang, 44, pp. 50-52.

Xian, Yiying (冼懿穎) (ed.) (2005), Call Me Taike!, Taipei: Wanglu yu shu. 
Xiao, Xueren (蕭學仁) (2010), Chong you Taiwan lao changjing: heibai de niandai caise de huiyi (Revisiting Old Taiwanese sights: Black-and-white Years, Colourful Memories), Taipei: Shangqi wenhua.

Xie, Shizong (謝世宗) (2015), Dianying yu shijue wenhua: yuedu Taiwan jingdian dianying (Film and Visual Culture: Reading the Classics of Taiwan Cinema), Taipei: Wunan.

Ye, Chunjiao (葉春嬌) (2010), Guozu rentong de zhuanzhe: Taiwan minzhong yu jingying de xushi (National Identity in Transition: Elite and Mass Narratives), Taipei: Daoxiang.

Yu, Emilie Yueh and Davis, Darrell William (2005), Taiwan Film Directors: A Treasure Island, New York: Columbia University Press.

Yuanliu Visual Book Editorial Office (遠流視覺書編輯室) (2002), Taiwan shiji huiwei 1895-2000 (Scanning Taiwan 1895-2000), vols. 1-3, Taipei: Yuanliu.

Zemanek, Adina (2017), 'Familiar Spaces: (National) Home in Contemporary Taiwanese Tourist Souvenirs', China Perspectives, 2, 7-17.

Zhou, Wanyao (周婉窈) (2016), Taiwanshi tushuo (Taiwan's History in Words and Images), Taipei: Lianjing. 
i A March 2014 speech by current Taipei mayor Ke Wenzhe can serve as an example: www.youtube.com/watch? $\mathrm{v}=3 \times \mathrm{xz} 607 \mathrm{Q} 22 \mathrm{wM} \&$ feature=youtu.be. Accessed 30 June 2017.

ii_http://eng.taiwan.net.tw/m1.aspx?sNo=0000235. Accessed 3 July 2017. 